\title{
PENGARUH INVESTASI, PDRB DAN PENYERAPAN TENAGA KERJA TERHADAP JUMLAH PENDUDUK MISKIN
}

\author{
Agus Budi Purnomo ${ }^{a}$ \\ Sri Kusreni ${ }^{\text {b }}$ \\ ${ }^{a}$ Sekolah Pascasarjana Universitas Airlangga ${ }^{b}$ Fakultas Ekonomi dan Bisnis Universitas Airlangga \\ Email: agus.budi.purnomo@gmail.com ${ }^{a}$; srikusreni54@gmail.com ${ }^{\text {b }}$
}

ARTICLE HISTORY

Received:

11 July 2019

Revised

10 August 2019

Accepted:

2 September 2019

Online available:

10 November 2019

Keywords:

Path analysis, investment,

Employment

Kata Kunci:

Path analysis, investasi, penyerapan tenaga kerja

\begin{abstract}
Introduction: During 2009-2013, the percentage of poor people in East Java was always above the national level. Based on this background, this study aims to examine and analyze the effect of investment, Gross Regional Domestic Product (GRDP), and labor absorption on the number of poor people in districts and cities in East Java

Methods: This study uses the path analysis method. This method was chosen because it is able to explain the direct and indirect effects between the independent variables and between the independent variables and the dependent variable based on a model built from previous theory and research.

Results: The results showed that investment directly had a positive effect on GRDP and employment. Meanwhile, GDP has a direct negative effect on the number of poor people, and employment has a direct positive effect on the number of poor people. So that investment indirectly has a negative effect on the number of poor people through PDRB, and investment indirectly has a positive effect on the number of poor people through employment.

Conclusion and suggestion: Regencies or cities whose economy is dominated by the industrial, service and trade sectors such as Sidoarjo regency, Gresik regency, Surabaya city, Malang city and the majority of other cities in East Java Province, which so far have low labor absorption, require labor intensive investment. so as to be able to absorb more labor which in turn will reduce the number of poor people.
\end{abstract}

*Correspondence:

Name:

E-mail: ....... 


\begin{abstract}
ABSTRAK
Jawa Timur adalah salah satu provinsi berkinerja ekonomi bagus: pertumbuhan ekonomi tinggi disertai peningkatan Investasi, penyerapan tenaga kerja, dan penurunan kemiskinan. Meskipun demikian, tingkat kemiskinan Jawa Timur masih relatif tinggi. Selama 2009-2013, persentase penduduk miskin Jawa Timur selalu di atas nasional Berdasarkan latar belakang tersebut penelitian ini bertujuan menguji dan menganalisis pengaruh investasi,Produk Domestik Regional Bruto (PDRB), dan penyerapan tenaga kerja terhadap jumlah penduduk miskin kabupaten dan kota di Jawa Timur tahun 20092013 dengan menggunakan metode path analysis. Metode ini dipilih karena mampu menjelaskan pengaruh langsung dan tidak langsung antarvariabel bebas maupun antara variabel-variabel bebas dengan variabel terikat berdasarkan model yang dibangun dari teori maupun penelitian sebelumnya. Hasil penelitian menunjukkan bahwa investasi secara langsung berpengaruh positif terhadap PDRB dan penyerapan tenaga kerja. Sementara PDRB secara langsung berpengaruh negatif terhadap jumlah penduduk miskin, dan penyerapan tenaga kerja secara langsung berpangaruh positif terhadap jumlah penduduk miskin. Sehingga Investasi secara tidak langsung berpengaruh negatif terhadap jumlah penduduk miskin melalui PDRB, dan investasi secara tidak langsung berpengaruh positif terhadap jumlah penduduk miskin melalui penyerapan tenaga kerja.
\end{abstract}

\title{
INTRODUCTION
}

Dalam kegiatan perekonomian, pertumbuhan ekonomi berarti perkembangan fisik produksi barang dan jasa yang berlaku di suatu negara, seperti pertambahan jumlah produksi barang industri, perkembangan infrastruktur, pertambahan jumlah sekolah, pertambahan produksi sektor jasa, dan pertambahan produksi barang modal (Sukirno, 2010: 423). Menurut Nafziger (2006: 48), pertumbuhan ekonomi merupakan pertambahan output per kapita suatu negara.

Pertumbuhan ekonomi perlu dibedakan dengan pembangunan ekonomi meskipun kedua istilah tersebut menjelaskan perkembangan ekonomi. Pertumbuhan ekonomi mengukur pertambahan output perekonomian di suatu wilayah, sementara pembangunan ekonomi menggambarkan pertumbuhan ekonomi yang diikuti oleh perubahan struktur dan corak perekonomian seperti penurunan kontribusi sektor pertanian dan peningkatan kontribusi sektor industri dan jasa atau peningkatan kualitas pendidikan dan keterampilan tenaga kerja.

Salah satu indikator yang digunakan untuk mengukur perekonomian suatu daerah pada periode tertentu adalah tingkat pertumbuhan Produk Domestik Regional

Published by University of Airlangga.

This is an open access article under the CC BY license (https://creativecommons.org/licenses/by-sa/4.0/) 
Bruto (PDRB). Produk Domestik Regional Bruto (PDRB) merupakan indikator dalam mengukur kinerja perekonomian suatu daerah, faktor yang mempengaruhi PDRB antara lain adalah adanya belanja modal yang mampu meningkatkan produksi. Akumulasi modal atau biasa disebutkan dengan istilah investasi ini memainkan peranan penting dalam menggerakkan kehidupan ekonomi bangsa, karena pembentukan modal dapat memperbesar kapasitas produksi, menaikkan pendapatan nasional, maupun menciptakan lapangan kerja baru yang nantinya akan semakin memperluas kesempatan kerja (Todaro dan Smith,2006;68).

Jawa Timur merupakan salah satu provinsi dengan tingkat pertumbuhan ekonomi yang cukup tinggi di Indonesia. Pada tahun 2012 tingkat pertumbuhan ekonomi Jawa Timur mencapai 7,27 \%. Selain itu wilayah Jawa Timur secara ekonomi menyumbang lebih kurang $16 \%$ dari perekonomian nasional (BPS Provinsi Jawa Timur, 2013).

Tingginya pertumbuhan ekonomi diharapkan mampu menjadi pertumbuhan ekonomi yang inklusif dan mampu mengurangi kemiskinan. Kontribusi pertumbuhan ekonomi terhadap penanggulangan kemiskinan dapat diukur dengan elastisitas pertumbuhan ekonomi terhadap kemiskinan atau growth elasticity of poverty (GEP). GEP menunjukkan perubahan persentase ukuran kemiskinan pada setiap 1 persen pertumbuhan ekonomi (Stöterau, 2010:3). Sebagaimana terlihat pada Tabel 1, sejak tahun 2010 nilai GEP Jawa Timur turun drastis. Jika pada tahun 2009 nilai GEP Jawa Timur sebesar 2,1, maka pada tahun 2010 dan 2011 hanya sebesar 0,72 dan 0,88 persen. $\mathrm{Hal}$ ini berarti kontribusi pertumbuhan ekonomi dalam mengurangi kemiskinan semakin mengecil.

Tabel 1

Nilai GEP Provinsi Jawa Timur Tahun 2009 - 2013

\begin{tabular}{cccc}
\hline Tahun & Penurunan Kemiskinan (\%) & Pertumbuhan PDRB (\%) & GEP** \\
\hline 2009 & 10,51 & 5,01 & 2,10 \\
2010 & 4,80 & 6,68 & 0,72 \\
2011 & 6,32 & 7,22 & 0,88 \\
2012 & 4,48 & 7,27 & 0,61 \\
2013 & 1,98 & 6,55 & 0,30 \\
\hline
\end{tabular}

Sumber: BPS, diolah.

*)Penurunan kemiskinan: persentase penurunan jumlah penduduk miskin dibanding tahun sebelumnya

**) GEP = rasio penurunan kemiskinan terhadap pertumbuhan PDRB

Dibandingkan dengan tingkat kemiskinan secara nasional, tingkat kemiskinan di Jawa Timur masih tergolong relative tinggi. Persentase penduduk miskin di Jawa Timur memang mengalami penurunan dari tahun ke tahun, mulai dari 18,51\% pada Maret 2008 
menjadi $12,73 \%$ pada September 2013. Akan tetapi selama periode tersebut persentase penduduk miskin Jawa Timur masih lebih tinggi daripada persentase penduduk miskin nasional yang terus menurun dari 15,42\% pada Maret 2008 menjadi 11,47\% pada September 2013.

Masalah lain yang dihadapi Jawa Timur terkait kemiskinan adalah adanya beberapa wilayah dengan kemiskinan tinggi yang tidak pernah berubah selama lima tahun terakhir (2009-2013). Wilayah kabupaten dan kota di Provinsi Jawa Timur dengan tingkat kemiskinan absolut tinggi pada tahun 2009 sampai 2013 adalah Kabupaten Sampang, Kabupaten Bangkalan, Kabupaten Probolinggo, Kabupaten Sumenep, Kabupaten Pamekasan. Wilayah kabupaten dan kota di Provinsi Jawa Timur dengan tingkat kemiskinan absolut rendah pada tahun 2009 sampai 2013 adalah Kota Batu, Kota Malang, Kota Madiun, Kota Surabaya, Kota Mojokerto (BPS, 2013)

Terdapat banyak faktor yang mempengaruhi kemiskinan, seperti pertumbuhan ekonomi, dan penyerapan tenaga kerja. Sementara itu pertumbuhan ekonomi dan penyerapan dapat dipengaruhi oleh investasi. Sehingga diduga secara tidak langsung investasi dapat mempengaruhi kemiskinan. Berbagai literatur ekonomi menyebutkan korelasi positif antara pertumbuhan ekonomi dan pengurangan kemiskinan. Nallari dan Griffith (2011:64) menyatakan bahwa pertumbuhan yang berkelanjutan akan mengurangi kemiskinan. Berbagai studi lintas negara telah menyimpulkan bahwa penentu utama pengurangan kemiskinan adalah pertumbuhan ekonomi yang mantab.

Dalam teori ekonomi makro, dari sisi pengeluaran, pendapatan regional bruto adalah penjumlahan dari berbagai variabel termasuk di dalamnya adalah investasi. Ada beberapa hal yang sebenarnya berpengaruh dalam soal investasi ini. Investasi sendiri terdiri oleh investasi asing (Penanaman Modal Asing) dan domestik (Penanaman Modal Dalam Negeri). Investasi diharapkan akan memacu pertumbuhan ekonomi karena dengan adanya investasi baru akan membuka lapangan kerja baru, bertambahnya fasilitas produksi baru yang akhirnya diharapkan dapat meningkatkan output suatu daerah.

Menurut Boediono $(2001 ; 47)$ investasi adalah pengeluaran oleh sektor produsen untuk pembelian barang dan jasa untuk menambah stok yang digunakan atau untuk perluasan pabrik. Investasi akan menambah jumlah (stock) dari capital. Keberhasilan daerah untuk meningkatkan daya tariknya terhadap investasi salah satunya tergantung dari kemampuan daerah dalam merumuskan kebijakan yang berkaitan dengan investasi dan dunia usaha serta peningkatan kualitas pelayanan terhadap masyarakat.

Penyerapan tenaga kerja juga diduga berpengaruh terhadap tingkat kemiskinan. Semakin banyak tenaga kerja yang terserap diharapkan mampu mengurangi tingkat kemiskinan. Apabila penyerapan tenaga kerja tidak diimbangi dengan penurunan tingkat 
kemiskinan, maka kualitas lapangan kerja yang tersedia perlu diperbaiki misalnya dengan perbaikan tingkat upah karyawan atau pemberian jaminan sosial. Untuk wilayah Jawa Timur, kondisi penyerapan tenaga kerja cenderung semakin baik dari tahun ke tahun.

Melalui berbagai uraian di atas, dapat dilihat bahwa terdapat beberapa permasalahan di Jawa Timur terkait penanggulangan kemiskinan, yaitu antara lain:

1. Semakin rendahnya kontribusi pertumbuhan ekonomi dalam menurunkan kemiskinan. Pertumbuhan ekonomi memang semakin meningkat, tetapi kontribusinya terhadap pengurangan kemiskinan cenderung menurun.

2. persentase penduduk miskin yang relatif tinggi, lebih tinggi dibanding nasional.

3. Adanya kantong kemiskinan yang tidak berubah. Hal ini menunjukkan adanya permasalahan serius yang perlu dipecahkan di daerah tersebut.

Adanya ketiga masalah tersebut di atas menunjukkan perlunya suatu penelitian yang mendalam mengenai faktor-faktor yang mempengaruhi kemiskinan di Jawa Timur, tidak hanya faktor pertumbuhan ekonomi, tetapi juga faktor-faktor lain di luar pertumbuhan ekonomi, seperti faktor ketenagakerjaan dan investasi. Dalam penelitian ini kedua faktor tersebut didekati dan dinyatakan dalam variabel penyerapan tenaga kerja dan realisasi investasi.

\section{LITERATURE REVIEW}

\section{The traditional society}

Komponen percepatan pertumbuhan ekonomi seperti akumulasi modal, pertumbuhan penduduk, dan kemajuan teknologi, investasi sebagai akumulasi modal menjadi faktor dominan dalam memperbaiki dan melipatgandakan kualitas sumber daya fisik dan sumber daya manusia (Todaro \& Smith, 2006, 32). Pertumbuhan ekonomi adalah suatu proses bukan suatu gambaran ekonomi pada suatu waktu yang dinamis dari suatu perekonomian yaitu melihat bagaimana perekonomian berkembang atau berubah dari waktu ke waktu. Pertumbuhan ekonomi merupakan suatu proses kenaikan output perkapita dalam jangka panjang yang ditekankan pada tiga aspek: proses; output perkapita; dan jangka panjang.

Adapun untuk menghitung laju pertumbuhan ekonomi pada suatu negara berdasarkan konsep GDP sebagai berikut:

$g t=\frac{P D B_{t}-P D B_{t-1}}{P D B_{t-1}} \times 100 \%$

dimana gt adalah pertumbuhan ekonomi pada tahun $t$, PDBt adalah besarnya Produk Domestik Bruto pada tahun ke t, dan GDP $t_{t-1}$ adalah besarnya PDB pada tahun ke t-1.

Pembangunan dan kegiatan investasi merupakan dua hal yang sulit dipisahkan, pembangunan tanpa kegiatan investasi berarti mengurangi pertumbuhan ekonomi. Investasi menurut Sukirno adalah pengeluaran atau pembelanjaan penanaman modal bagi perusahaan untuk membeli barang barang modal dan perlengkapan produksi untuk 
menambah kemampuan produksi barang dan jasa yang tersedia dalam satu perekonomian (Sukirno,2010;107). Menurut konsep Harod Domar mengenai pertumbuhan untuk mencapai pertumbuhan ekonomi diperlukan investasi yang memadai. Atas dasar itulah maka selaku pengambil keputusan, pemerintah berkepentingan untuk mengetahui seberapa besar investasi yang dibutuhkan untuk mencapai pertumbuhan yang diharapkan serta sejauh mana dampak investasi pada suatu sektor ataupun wilayah.

\section{Previous Study}

Beberapa penelitian yang membahas masalah pertumbuhan ekonomi, penyerapan tenaga kerja, dan kemiskinan antara lain: Penelitian Donaldson (2008) yang meneliti respon pengurangan kemiskinan terhadap pertumbuhan ekonomi. Berangkat dari kesimpulan umum bahwa pertumbuhan ekonomi berkontribusi positif terhadap pengurangan kemiskinan, penelitian ini membahas kasus-kasus khusus respon pengurangan kemiskinan terhadap pertumbuhan ekonomi yang berbeda dari perkiraan. Respon dibagi menjadi dua golongan, yaitu perkecualian negatif dan perkecualian positif. Perkecualian negatif apabila tingkat pengurangan kemiskinan akibat pertumbuhan ekonomi berada di bawah nilai yang diharapkan dan perkecualian positif apabila di atas nilai yang diharapkan. Penelitian ini menyimpulkan adanya faktor-faktor lain yang menyertai pertumbuhan ekonomi dalam mendorong pengurangan kemiskinan. Kebijakan redistribusi pendapatan, reformasi agraria, jaring pengaman sosial, dan pengurangan pengangguran adalah beberapa faktor yang menjadikan respon pengurangan kemiskinan terhadap pertumbuhan ekonomi menjadi lebih baik daripada yang diharapkan. Sementara ketiadaan faktor-faktor tersebut beserta tata kelola pemerintahan yang buruk, korupsi, dan bencana alam menjadikan respon pengurangan kemiskinan terhadap pertumbuhan ekonomi menjadi lebih buruk daripada yang diperkirakan.

Bende Antony (1997) melakukan penelitian di 5 (lima) negara ASEAN, hasil penelitian menyatakan adanya hubungan positif antara investasi penanaman modal asing terhadap pertumbuhan ekonomi di negara negara ASEAN tersebut. Perbedaan dengan penelitian ini adalah, penelitian ini meneliti lebih lanjut pengaruh Penanaman Modal terhadap PDRB, Penyerapan Tenaga Kerja dan Kemiskinan.

Dollar dan Kraay (2000) menyatakan pertumbuhan ekonomi cenderung menaikan pendapatan masyarakat miskin secara proporsional terhadap pertumbuhan secara keseluruhan dan faktor kunci untuk menghasilkan pertumbuhan ekonomi adalah investasi penanaman modal asing. Perbedaan dengan penelitian ini adalah disini tidak 
hanya meneliti penanaman modal asing saja, akan tetapi keseluruhan nilai investasi termasuk investasi domestik.

Roemmer dan Goggerty (1997) mengemukakan rata-rata masyarakat miskin akan memperoleh pertumbuhan ekonomi. Penelitian mereka menemukan kenaikan angka GDP per kapita akan menaikkan pendapatan rata rata masyarakat miskin. Perbedaan dengan penelitian ini adalah penelitian ini memasukkan variabel antara yaitu penyerapan tenaga kerja, dalam meneliti pengaruh PDB terhadap kemiskinan.

Penelitian Balisacan dan Fuwa (2004) yang menganalisis proses pertumbuhan ekonomi dan pengurangan kemiskinan di Filipina dengan menggunakan model pertumbuhan neoklasik dan data ekonomi di tingkat provinsi. Kinerja pertumbuhan ekonomi dan pengurangan kemiskinan di Filipina selama tahun 1965-1995 relatif lebih buruk dibanding negara-negara tetangga di Asia Tenggara. Peneliti menganalisis apakah hal ini akibat lambatnya respon penurunan kemiskinan terhadap pertumbuhan ekonomi, tingginya ketimpangan pendapatan, atau kebijakan politik ekonomi yang tidak tepat. Hasil penelitian menunjukkan bahwa rendahnya respon pengurangan kemiskinan terhadap pertumbuhan ekonomi adalah akibat rendahnya pertumbuhan di sektor pertanian.

\section{RESEARCH METHODS}

Metode analisis yang digunakan adalah analisis jalur (path analysis). Analisis jalur digunakan untuk mengetahui hubungan langsung maupun tak langsung antara variabelvariabel bebas dengan variabel terikat. Data yang digunakan dalam penelitian ini adalah data sekunder yaitu data Investasi, Pertumbuhan ekonomi, Jumlah penyerapan tenaga kerja, dan jumlah penduduk miskin yang diperoleh dari Badan Pusat Statistik (BPS) Provinsi Jawa Timur maupun BPS Pusat. Seluruh data tersebut merupakan data kabupaten dan kota di Jawa Timur tahun 2009 - 2013.

Investasi adalah Nilai Realisasi Penanaman Modal Asing (PMA) dan Penanaman Modal Dalam Negeri (PMDN) di Kabupaten / Kota Provinsi Jawa Timur yang dinyatakan dalam satuan Rupiah. Produk Domestik Regional Bruto (PDRB) adalah Nilai PDRB atas dasar harga konstan tahun 2000 yang dinyatakan dalam satuan Rupiah. Penyerapan tenaga kerja adalah jumlah penduduk berumur 15 tahun ke atas yang bekerja. Bekerja menurut BPS adalah kegiatan ekonomi yang dilakukan oleh seseorang dengan maksud memperoleh atau membantu memperoleh pendapatan atau keuntungan paling sedikit 1 jam (tidak terputus) dalam seminggu yang lalu yang dinyatakan dalam satuan Jiwa. Jumlah penduduk miskin adalah jumlah penduduk yang berada di bawah garis kemiskinan. Menurut BPS, garis kemiskinan merupakan batas pendapatan yang diperlukan untuk memenuhi kebutuhan minimal kalori yang diperlukan tubuh untuk beraktivitas, ditambah dengan kebutuhan non makanan (perumahan, pakaian, 
pendidikan, kesehatan, transpor, dan kebutuhan pokok lainnya) yang dinyatakan dalam satuan.

\section{RESULT AND ANALYSIS}

Result should be presented continuously start from main result until supporting results. Unit of measurement used should follow the prevailing international system. It also allowed to present diagram, table, picture, and graphic followed by narration of them.

Analisis pertama yang dilakukan dalam penelitian ini adalah penentuan koefisien pengaruh antarvariabel, baik pengaruh langsung maupun tak langsung. Pengaruh langsung yang diukur adalah pengaruh variabel investasi $(x 1)$ terhadap dua variabel Intervening yaitu PDRB ( $x 2)$, dan jumlah tenaga kerja $(x 3)$, Serta pengaruh masing2 variabel intervening PDRB $(x 2)$ dan Jumlah Tenaga Kerja $(x 3)$ terhadap variabel jumlah penduduk miskin (y), Adapun pengaruh tidak langsung yang diukur adalah pengaruh variabel investasi $(x 1)$ terhadap variabel jumlah penduduk miskin $(y)$ melalui variabel PDRB (x2) dan jumlah tenaga kerja (x3) .

Tabel 2

Hasil Regresi

\begin{tabular}{lrrrrrr}
\hline & & & Estimate & S.E. & C.R. & P Label \\
\hline $\mathrm{X} 2$ & $<---$ & $\mathrm{X} 1$ & 2223.339 & 105.770 & 21.020 & $* * *$ \\
$\mathrm{X3}$ & $<---$ & $\mathrm{X} 1$ & 26.556 & 3.079 & 8.625 & $* * *$ \\
$\mathrm{Y}$ & $<---$ & $\mathrm{X} 2$ & -.002 & .000 & -10.102 & $* * *$ \\
$\mathrm{Y}$ & $<---$ & $\mathrm{X} 3$ & .284 & .013 & 22.350 & $* * *$ \\
\hline
\end{tabular}

\begin{tabular}{lrrr}
\hline & & \multicolumn{2}{c}{ Estimate } \\
\hline$X 2$ & $<---$ & $X 1$ & .837 \\
$X 3$ & $<---$ & $X 1$ & .531 \\
$Y$ & $<---$ & $X 2$ & -.430 \\
$Y$ & $<---$ & $X 3$ & .951
\end{tabular}

Sumber: Data Diolah (software AMOS)

Hasil analisis statistik menunjukkan bahwa investasi berpengaruh signifikan secara langsung terhadap PDRB dengan koefisien pengaruh sebesar 0,837. Angka ini 
menunjukkan investasi berpengaruh positif atau berbanding lurus terhadap PDRB. Artinya semakin tinggi investasi, semakin tinggi PDRB di sebuah daerah.

Hasil analisis tersebut memperkuat fakta empiris yang ditampilkan oleh data statistik. Sebagaimana ditunjukkan pada Tabel 5.2 halaman 59, daerah-daerah yang memiliki investasi tinggi, seperti Kota Surabaya (20 - 36.5 Triliun Rupiah ), Kabupaten Sidoarjo (8,2 - 20,1 Triliun Rupiah) dan Kabupaten Kabupaten Gresik (2,5 - 15 Triliun Rupiah) PDRB nya juga cenderung tinggi yaitu Kota Surabaya (85-109 Triliun Rupiah), Kabupaten Sidoarjo (26 - 32 Triliun Rupiah) dan Kabupaten Gresik (15 - 20 Triliun Rupiah). Sebaliknya daerah-daerah dengan investasi rendah seperti Kota Pasuruan, Kota Madiun dan Kota Blitar (kurang dari 0,320 Triliun Rupiah) tingkat PDRB nya juga rendah (kurang dari 2,5 Triliun Rupiah),

Temuan ini sesuai dengan teori ICOR Incremental Capital Output Ratio (ICOR) menunjukkan hubungan jumlah kenaikan output $(\Delta \mathrm{Y})$ disebabkan kenaikan tertentu pada stok modal $(\Delta K)$. Semakin tinggi peningkatan stok modal, semakin tinggi pula output yang dihasilkan. Ini dapat digambarkan sebagai $\Delta K / \Delta Y$ (Jhingan, 1999). Selanjutnya Arsyad (1999) menyatakan bahwa pentingnya COR dan ICOR ini tampak ketika menguji konsistensi antara target pembangunan dengan tambahan modal yang mungkin terkumpul dari tabungan yang berjalan. Dalam rangka memperkirakan kebutuhan dana untuk mencapai pertumbuhan, diperlukan perkiraan mengenai volume investasi, baik yang bersal dari pemerintah maupun swasta (PMDN/PMA) untuk mencapai sasaran pertumbuhan output tersebut.

\section{Pengaruh Investasi Terhadap Jumlah Tenaga Kerja}

Hasil analisis statistik menunjukkan bahwa investasi berpengaruh signifikan secara langsung terhadap jumlah tenaga kerja dengan koefisien pengaruh sebesar 0,531. Angka ini menunjukkan investasi berpengaruh positif atau berbanding lurus terhadap jumlah penyerapan tenaga kerja. Artinya semakin tinggi investasi, semakin tinggi penyerapan tenaga kerja di sebuah daerah.

Hasil analisis tersebut memperkuat fakta empiris yang ditampilkan oleh data statistik. , daerah-daerah yang memiliki investasi tinggi, seperti Kota Surabaya (20 - 36.5 Triliun Rupiah), Kabupaten Sidoarjo (8,2 - 20,1 Triliun Rupiah) dan Kabupaten Kabupaten Gresik (2,5 - 15 Triliun Rupiah) jumlah penyerapan tenaga kerjanya nya juga relatif tinggi. Sebaliknya daerah-daerah dengan investasi rendah seperti Kota Pasuruan, Kota Madiun dan Kota Blitar ( kurang dari 0,32 Triliun Rupia) tingkat penyerapan tenaga kerjanya juga rendah,

Hal ini sesuai dengan teori dan penelitian sebelumnya bahwa adanya investasi akan mampu menyerap tambhan tenaga kerja.Investasi memainkan peran penting dalam menggerakkan kehidupan ekonomi bangsa, karena pembentukan modal memperbesar kapasitas produksi, menaikkan pendapatan nasional maupun menciptakan 
lapangan kerja baru, dalam hal ini akan semakin memperluas kesempatan kerja (Todaro,2003)

\section{Pengaruh PDRB Terhadap Jumlah Penduduk Miskin}

Berdasarkan model yang dikembangkan, PDRB mempengaruhi jumlah penduduk miskin . PDRB berpengaruh negatif dan signifikan terhadap jumlah penduduk miskin dengan koefisien pengaruh sebesar -0,430. Hal ini sejalan dengan teori maupun penelitian penelitian terdahulu yang menyatakan bahwa pertumbuhan ekonomi dalam jangka panjang akan menurunkan angka kemiskinan.

Ferreira dkk. (2010) pernah meneliti faktor-faktor penyebab rendahnya kontribusi pertumbuhan ekonomi dalam menurunkan kemiskinan di Brasil. Selama periode 1985-2004, tingkat kemiskinan di Brasil hanya turun dari 33\% menjadi 29\%, sementara di negara berkembang lainnya turun drastis dari $33 \%$ menjadi $18 \%$. Dengan membagi agregat PDB ke dalam beberapa wilayah dan sektor, penelitian ini menemukan bahwa efektifitas pertumbuhan ekonomi dalam menurunkan kemiskinan bervariasi di berbagai sektor, wilayah, dan waktu. Pertumbuhan sektor jasa ternyata lebih menurunkan kemiskinan dibandingkan sektor pertanian dan industri. Efektifitas pertumbuhan di sektor industri dalam menurunkan kemiskinan bervariasi menurut wilayah dan variasi ini berhubungan dengan kualitas SDM masing-masing wilayah.

\section{Pengaruh Jumlah Tenaga Kerja Terhadap Jumlah Penduduk Miskin}

Pada penelitian ini penyerapan tenaga kerja berpengaruh signifikan terhadap jumlah penduduk miskin dengan koefisien pengaruh sebesar 0,951. Angka positif menunjukkan bahwa penyerapan tenaga kerja berbanding lurus dengan jumlah penduduk miskin. Semakin tinggi penyerapan tenaga kerja, semakin tinggi pula jumlah penduduk miskin. Semakin rendah penyerapan tenaga kerja, semakin rendah pula jumlah penduduk miskin.

Temuan ini bertentangan dengan teori yang menyatakan bahwa peningkatan penyerapan tenaga kerja akan mengurangi tingkat kemiskinan. Okun (1962) dalam Arsyad (2010:133) memberikan analisis bahwa salah satu cara mengatasi kemiskinan adalah mengadakan investasi untuk tenaga kerja sebagai cara untuk menurunkan tingkat pengangguran. Nallari dan Griffith (2011:269) juga menyatakan bahwa lapangan kerja adalah jalan keluar dari kemiskinan.

Setidaknya ada dua kemungkinan yang dapat menjelaskan mengapa penyerapan tenaga kerja justru menambah jumlah penduduk miskin. Pertama, adalah karena tenaga kerja yang terserap bukan dari kelompok penduduk miskin. Kemungkinan ini sesuai dengan penelitian Messkoub (2008) yang menemukan bahwa apabila lapangan kerja 
yang tersedia membutuhkan keahlian tinggi yang tidak dimiliki oleh penduduk miskin, maka tentu saja mereka tidak akan mendapat manfaat dari lapangan kerja yang tersedia tersebut.

Kemungkinan kedua adalah jumlah tenaga kerja memang meningkat tetapi pendapatan yang diterima oleh tenaga kerja tidak mampu mengangkat taraf ekonomi mereka sampai di atas garis kemiskinan. Sebagaimana dijelaskan, penyerapan tenaga kerja lebih besar terjadi pada daerah-daerah miskin yang struktur ekonominya didominasi oleh sektor pertanian. Sementara menurut keterangan BPS (2013c), tingkat upah pada sektor pertanian paling rendah bila dibandingkan dua sektor utama lainnya, yaitu sektor industri pengolahan dan sektor perdagangan, hotel, dan restoran. Nilai Tukar Petani (NTP) Jawa Timur yang mencerminkan tingkat kesejahteraan petani dengan mengukur kemampuan tukar produk (komoditas) yang dihasilkan/dijual petani dibandingkan dengan barang/jasa yang dibutuhkan petani baik untuk proses produksi maupun untuk konsumsi rumah tangga cenderung rendah yaitu berkisar antara 98.19 102.16 selama tahun 2009 - 2013 (BPS, 2013b). NTP yang rendah menunjukkan rendahnya daya beli petani untuk memenuhi kebutuhan hidup sehari-hari dari pendapatan yang diperoleh dari sektor pertanian. Rendahnya NTP ini bisa jadi karena produktifitas sektor pertanian yang rendah akibat semakin sempitnya luas lahan yang dapat diolah keluarga petani. Menurut hasil Sensus Pertanian Tahun 2013 yang dilakukan oleh BPS, jumlah lahan pertanian di Jawa Timur pada tahun 2013 rata-rata hanya 0,37 hektar per keluarga petani.

\section{Pengaruh Investasi Terhadap Jumlah Penduduk Miskin melalui PDRB}

Hasil analisis menunjukkan bahwa investasi secara tidak langsung berpengaruh negatif terhadap jumlah penduduk miskin melalui variabel PDRB dengan koefisien pengaruh sebesar - 0,359. Semakin tinggi investasi akan mendorong pertumbuhan PDRB yang akhirnya akan menurunkan jumlah penduduk miskin. Hal ini sesuai dengan Klein, Aaron dan Hadjimichael (2001) yang menyatakan adanya investasi akan menstimulasi pertumbuhan ekonomi sehingga menurunkan angka kemiskinan. Selain itu investasi juga akan meningkatkan kualitas pertumbuhan ekonomi dan merupakan sarana untuk menurunkan tingkat kemiskinan.

Penelitian Donaldson (2008) meneliti respon pengurangan kemiskinan terhadap pertumbuhan ekonomi. Penelitian ini menyimpulkan adanya faktor-faktor lain yang menyertai pertumbuhan ekonomi dalam mendorong pengurangan kemiskinan. Kebijakan redistribusi pendapatan, reformasi agraria, jaring pengaman sosial, dan pengurangan pengangguran adalah beberapa faktor yang menjadikan respon pengurangan kemiskinan terhadap pertumbuhan ekonomi menjadi lebih baik daripada yang diharapkan. Sementara ketiadaan faktor-faktor tersebut beserta tata kelola pemerintahan yang buruk, korupsi, dan bencana alam menjadikan respon pengurangan 
kemiskinan terhadap pertumbuhan ekonomi menjadi lebih buruk daripada yang diperkirakan.

\section{Pengaruh Investasi Terhadap Jumlah Penduduk Miskin melalui Penyerapan Tenaga Kerja}

Hasil analisis menunjukkan bahwa investasi secara tidak langsung berpengaruh positif terhadap jumlah penduduk miskin melalui variabel penyerapan tenaga kerja dengan koefisien pengaruh sebesar 0,504 . Hal ini menunjukan bahwa investasi terbukti mampu menyerap tambahan tenaga kerja akan tetapi penambahan tenaga kerja itu tidak mampu menurunkan jumlah penduduk miskin.

Seperti dijelaskan diatas ada dua penyebab tentang hal ini pertama apabila lapangan kerja yang tersedia membutuhkan keahlian tinggi yang tidak dimiliki oleh penduduk miskin, maka tentu saja mereka tidak akan mendapat manfaat dari lapangan kerja yang tersedia tersebut, sehingga peningkatan lapangan kerja tersebut tidak dapat menurunkan jumlah penduduk miskin. Kemungkinan kedua adalah jumlah tenaga kerja memang meningkat tetapi pendapatan yang diterima oleh tenaga kerja tidak mampu mengangkat taraf ekonomi mereka sampai di atas garis kemiskinan.

\section{CONCLUSION}

Berdasarkan hasil penelitian dan pembahasan pada bab-bab sebelumnya, dapat diambil beberapa kesimpulan yaitu investasi di kabupaten/kota di provinsi Jawa Timur berpengaruh positif secara signifikan terhadap PDRB. Hal ini berarti bahwa semakin tinggi investasi maka akan semakin tinggi pula PDRB yang dihasilkan. Investasi di kabupaten/kota di provinsi Jawa Timur berpengaruh positif secara signifikan terhadap penyerapan tenaga kerja. Hal ini berarti bahwa semakin tinggi investasi maka akan semakin tinggi pula lapangan pekerjaan yang tersedia. PDRB di kabupaten/kota di provinsi Jawa Timur berpengaruh negatif signifikan terhadap jumlah penduduk miskin. Hal ini berarti semakin tinggi PDRB maka akan semakin sedikit jumlah penduduk miskin. Penyerapan tenaga kerja di kabupaten/kota di provinsi Jawa Timur berpengaruh positif signifikan terhadap jumlah penduduk miskin. Hal ini tidak berarti bahwa penyerapan tenaga kerja mengakibatkan terjadinya kemiskinan,tetapi karena penyerapan tenaga kerja lebih banyak terjadi pada sektor pertanian terutama pada kabupaten yang perekonomianya di dominasi oleh sektor pertanian seperti kabupaten Pacitan, kabupaten Probolinggo dan kabupaten Bondowoso. Dari 38 kabupaten dan kota di provinsi Jawa Timur mayoritas adalah daerah yang perekonomianya didominasi oleh sektor pertanian. Tingkat penghasilan yang rendah pada sektor pertanian tidak mampu membebaskan tenaga kerja yang bekerja di sektor tersebut dari kemiskinan. Sementara 
Jurnal Ekonomi dan Bisnis Airlangga, Vol. 29, No.2, June - November 2019

tingkat penyerapan tenaga kerja pada sektor industri pengolahan dan sektor perdagangan, hotel, dan restoran relatif lebih rendah, meskipun tingkat penghasilannya tinggi. Investasi di kabupaten/kota di provinsi Jawa Timur secara tidak langsung berpengaruh secara negatif signifikan terhadap jumlah penduduk miskin melalui variabel PDRB. Hal ini berarti semakin besar nilai investasi makan akan menyebabkan PDRB semakin tinggi, yang mana nilai PDRB yang tinggi ini akan menurunkan jumlah penduduk miskin. Investasi di kabupaten/kota di provinsi Jawa Timur secara tidak langsung berpengaruh positif signifikan terhadap jumlah penduduk miskin. Hal ini berarti meningkatnya investasi akan menciptakan lapangan kerja. Akan tetapi meningkatnya penyerapan tenaga kerja tersebut tidak mampu menurunkan jumlah penduduk miskin.

Berdasarkan pada kesimpulan yang telah diambil dari hasil penelitian, maka terdapat beberapa saran yang dapat dijadikan pertimbangan dalam upaya mengatasi dan menurunkan tingkat kemiskinan pada masing-masing kabupaten/kota di Provinsi Jawa Timur:

1. Untuk kabupaten/kota yang perekonomiannya didominasi sektor pertanian dan banyak menyerap tenaga kerja seperti kabupaten Pacitan, kabupaten Probolinggo, kabupaten Bondowoso serta mayoritas kabupaten- kabupaten lain di Jawa timur perlu mendapatkan prioritas dalam perencanaan dan pelaksanaan pembangunan, terutama dalam kerangka peningkatan dan perbaikan nilai tukar petani. Pembangunan jaringan irigasi, pemberian subsidi secara tepat, dan penerapan sistem tunda jual produk pertanian merupakan beberapa alternatif strategi yang dapat ditempuh.

2. Untuk kabupaten/ kota yang perekonomianya didominasi sektor industri, jasa dan perdagangan seperti kabupaten Sidoarjo, kabupaten Gresik, kota Surabaya , kota Malang dan mayoritas kota-kota lain di Provinsi Jawa Timur yang selama ini penyerapan tenaga kerjanya rendah diperlukan investasi yang padat karya (labor intensive) sehingga mampu menyerap lebih banyak tenaga kerja yang pada akhirnya akan menurunkan jumlah penduduk miskin.

\section{REFERENCES}

Arsyad, L. 2010. Ekonomi Pembangunan. Yogyakarta: UPP STIM YKPN.

Bende Anthony. 1997. The role of FDI in the economic growth of the ASEAN-5 economies, with policy implications for the least developed countries University of Birmingham . Birmingham UK

Boediono, 1995, Teori Pertumbuhan Ekonomi. Yogyakarta: BPFE, Universitas Gadjah Mada.

BPS, 2009a, Analisis Indikator Makro Sosial dan Ekonomi Kabupaten/Kota Provinsi Jawa Timur. Badan Pusat Statistik Jawa Timur.

-----, 2009b, Keadaan Angkatan Kerja di Propinsi Jawa Timur Agustus 2009. Badan Pusat Statistik Jawa Timur.

-----, 2010a, Analisis Indikator Makro Sosial dan Ekonomi Kabupaten/Kota Provinsi Jawa Timur. Badan Pusat Statistik Jawa Timur.

-----, 2010b, Provinsi Jawa Timur. Badan Pusat Statistik Jawa Timur. 
-----, 2010c, Provinsi Jawa Timur dan Pemerintah Provinsi Jawa Timur. Badan Pusat Statistik Jawa Timur.

-----, 2010d, Keadaan Angkatan Kerja di Propinsi Jawa Timur Agustus 2010. Badan Pusat Statistik Jawa Timur.

-----, 2011a, Analisis Indikator Makro Sosial dan Ekonomi Kabupaten/Kota Provinsi Jawa Timur. Badan Pusat Statistik Jawa Timur.

-----, 2011b, Keadaan Angkatan Kerja di Propinsi Jawa Timur Agustus 2011. Badan Pusat Statistik Jawa Timur.

-----, 2012a, Analisis Indikator Makro Sosial dan Ekonomi Kabupaten/Kota Provinsi Jawa

Timur. Badan Pusat Statistik Jawa Timur.

-----, 2012b, Keadaan Angkatan Kerja di Propinsi Jawa Timur Agustus 2012. Badan Pusat

Statistik Jawa Timur.

-----, 2013a, Analisis Indikator Makro Sosial dan Ekonomi Kabupaten/Kota Provinsi Jawa

Timur. Badan Pusat Statistik Jawa Timur.

-----, 2013b, Provinsi Jawa Timur. Badan Pusat Statistik Jawa Timur.

------, 2013c, Keadaan Angkatan Kerja di Propinsi Jawa Timur Agustus 2013. Badan Pusat

Statistik Jawa Timur.

-----, 2012a, Produk Domestik Regional Bruto Provinsi Jawa Timur Kabupaten/Kota se Jawa Timur 2007-2011. Badan Pusat Statistik Jawa Timur.

------, 2012b, Data Makro Sosial Ekonomi Jawa Timur 2007-2011. Badan Pusat Statistik Jawa Timur.

-----, 2013a, Jawa Timur dalam Angka 2013. Badan Pusat Statistik Jawa Timur.

-----, 2013b, Indikator Ekonomi dan Sosial Jawa Timur Tahun 2012. Badan Pusat Statistik Jawa Timur.

-----, 2013c, Statistik Upah 2012. Badan Pusat Statistik.

Dollar .D dan Aart Kraay.2004 Trade, Growth, and Poverty The Economic Journal, Vol. 114 , No. 493

Donaldson, J.A. 2008. Growth is Good for Whom, When, How? Economic Growth and Poverty Reduction in Exceptional Cases. World Development. No. 11 (Vol. 36): 2127-2143.

Ferreira, F.H.G., P.G. Leite, dan M. Ravallion. 2010. Poverty reduction without economic growth? Explaining Brazil's poverty dynamics, 1985-2004. Journal of Development Economics. No.93: 20-36.

Gujarati, Damodar, N., 2003, Basic Econometrics, New York: McGraw-Hill.

Irawan, Drs., M.B.A., dan Drs. M. Suparmoko M.A., Ph.D. 2002. Pembangunan Ekonomi, Edisi 6. Yogyakarta: BPFE.

Ismawan, Bambang .2003.Peran Lembaga Keuangan Mikro. Journal of Indonesian Economy and Business Yogyakarta.

Jhingan, M.L., 2004, Ekonomi Pembangunan dan Perencanaan. Jakarta: Rajawali Press.

Klein,M, Aaaron, C dan Hadjimichael,B . 2001 Foreign Direct Investment and Poverty Reduction . Social Science Research Network 
Kuncoro, Mudrajat. 2000 . Ekonomi Pembangunan Teori, Masalah dan Kebijakan. Yogyakarta : UPP AMP YKPN

Lleras, Christy. 2005. Encyclopedia of Social Measurement. Vol 3. Pennsylvania: Elsevier Inc

Mankiew, N. G. 2007. Makroekonomi. Edisi 6. Terj. Jakarta: Penerbit Erlangga.

Messkoub, M. 2008. Economic Growth, Employment and Poverty in the Middle East and North Africa. The Hague: Institute of Social Studies.

Nafziger, E.W. 2006, Economic Development. Edisi 4. New York: Cambridge University Press.

Nallari, R. dan B. Griffith. 2011. Understanding Growth and Poverty: Theory, Policy, and Empirics. Washington DC: The World Bank.

Peraturan Gubernur Nomor 38 Tahun 2009 tentang Rencana Pembangunan Jangka Menengah Daerah (RPJMD) Provinsi Jawa Timur Tahun 2009 - 2014.

Stöterau, J. 2010. Estimating Growth Elasticities of Poverty. Berlin: Humboldt-Universität zu Berlin.

Sukirno, Sadono. 2010. Ekonomi Pembangunan Proses, Masalah dan Dasar Kebijakan Pembangunan. UI-Press. Jakarta.

Sirojuzilam dan Mahalli, K. 2010. Regional. Pembangunan, Perencanaan dan Ekonomi. USU Press. Medan.

Simanjuntak, Payaman. J., 1998, Pengantar Ekonomi Sumber Daya Manusia, Jakarta: FEUI.

Sloman, J. 2006. Economics. $6^{\text {th }}$ Edition. London: Prentice Hall.

Todaro, M.P. dan S.C. Smith. 2006. Pembangunan Ekonomi. Edisi 9. Jilid 1. Terj. Jakarta: Penerbit Erlangga. 